UDC 343.131 .5

LBC 67.410 .2

\title{
ON SOME PROBLEMS OF PRESERVING ATTORNEY-CLIENT PRIVILEGE IN THE CRIMINAL PROCEDURE
}

\author{
Irina A. Biryukova \\ Volgograd State University, Volgograd, Russian Federation
}

\begin{abstract}
Introduction: the article is devoted to some topical problems connected with safeguarding the information constituting attorney-client privilege by the attorney and other persons, in particular, the paralegal, the trainee attorney, other employees of the law firms. In this regard, in the work the author sets the purpose: the improvement of the legislation regarding the preservation of attorney-client privilege in the criminal procedure. To achieve this goal there were used the methods of scientific cognition: analysis, synthesis, comparison, and the specific scientific methods of studies: formal legal, technical legal. Results: on the basis of the current legislation there was argued the viewpoint that the paralegal, the trainee and other employees of the law firms shall not refuse to testify to the circumstances that became known to them in connection with their professional activities. In practice, it is impossible to exclude a situation when the paralegal, the trainee or another employee of the law firm will be called in evidence by the investigating authorities or the court, and, in case of refusal to testify as to the circumstances which in fact are the subject of attorney-client privilege, the indicated persons can be prosecuted under Art. 308 of the Criminal Code of the Russian Federation. Conclusions: it is proposed to amend paragraph 2 and 3 of Part 3 of Art. 56 of the Russian Federation Code of Criminal Procedure, outlining them in a new edition.
\end{abstract}

Key words: criminal procedure, witness immunity, attorney, attorney-client privilege, criminal liability.

УДК 343.131 .5

ББК 67.410 .2

\section{АДВОКАТСКАЯ ТАЙНА В УГОЛОВНОМ СУДОПРОИЗВОДСТВЕ}

\author{
Ирина Анатольевна Бирюкова \\ Волгоградский государственный университет, г. Волгоград, Российская Федерация
}

\begin{abstract}
Введение: статья посвящена актуальным проблемам, связанным с сохранением сведений, составляющих адвокатскую тайну, адвокатом, а также иными лицами, в частности, помощником, стажером адвоката, иными сотрудниками адвокатских образований. В связи с этим в работе поставлена цель: совершенствование законодательства в части сохранения адвокатской тайны в уголовном процессе. Для достижения поставленной цели были использованы методы научного познания: анализ, синтез, сравнение, а также частнонаучные методы исследования: формально-юридический, технико-юридический. Результаты: на основании действующего законодательства аргументирована позиция, что помощник, стажер адвоката и иные сотрудники адвокатских образований не вправе отказаться от дачи показаний об обстоятельствах, ставших им известными в связи с их профессиональной деятельностью. При этом на практике нельзя 궁 исключать ситуацию, когда помощник, стажер адвоката или иной сотрудник адвокатского образования \& будет вызван следственными органами или судом для допроса в качестве свидетеля, и в случае отказа от дачи показаний об обстоятельствах, фактически составляющих предмет адвокатской тайны, указанные лица могут быть привлечены к уголовной ответственности по ст. 308 УК РФ. Выводы: предлагается внести изменения в п. 2 и 3 ч. 3 ст. 56 УПК РФ, изложив их в новой редакции.

Ключевые слова: уголовное судопроизводство, свидетельский иммунитет, адвокат, адвокатская тайна, уголовная ответственность.
\end{abstract}




\section{Введение}

Никто не обязан показывать против себя самого (с лат. nemo tenetur se ipsum prodere vel accusare) - это правило, признаваемое в наши дни во всех основных правовых системах, было сформулировано еще в римском праве. В российском законодательстве данное положение закреплено на конституционном уровне (ст. 51 Конституции РФ).

В пункте 40 ст. 5 УПК РФ дано определение свидетельского иммунитета. Данное право предполагает свободное усмотрение субъекта на то, давать ему показания по уголовному делу или нет. Свидетельский иммунитет следует отличать от устранения от свидетельства, представляющего собой законодательно закрепленный запрет допрашивать некоторых лиц в качестве свидетелей об определенных обстоятельствах [2, с. 61]. Именно как устранение от свидетельства законодатель сформулировал положение ч. 3 ст. 56 УПК РФ («Не подлежат допросу в качестве свидетелей...»). Однако в действительности далеко не все из перечисленных там лиц полностью устраняются от свидетельства некоторые все же вправе давать свидетельские показания, как, например, член Совета Федерации, депутат Государственной Думы, когда дают на то свое согласие, и др. (п. 5 ч. 3 ст. 56 УПК РФ).

\section{Адвокат (защитник) как субъект адвокатской тайны}

В теории уголовного процесса весьма актуальна проблема свидетельского иммунитета адвоката, защитника (см.: [3-6]). Конституционный Суд РФ в своем Определении от 6 марта 2003 г. № 108-О указал, что уголовно-процессуальный закон не исключает права адвоката дать соответствующие показания в случаях, когда сам адвокат и его подзащитный заинтересованы в оглашении тех или иных сведений.

Федеральным законом от 17 апреля 2017 г. № 73-Ф3 «О внесении изменений в Уголовно-процессуальный кодекс Российской Федерации» в п. 2, 3 ч. 3 ст. 56 УПК РФ были внесены изменения. Теперь, по смыслу закона, не подлежат допросу в качестве свидете- лей адвокат, защитник подозреваемого, обвиняемого об обстоятельствах, ставших ему известными в связи с обращением к нему за юридической помощью или в связи с ее оказанием, за исключением случаев, если о допросе в качестве свидетеля ходатайствует адвокат, защитник подозреваемого, обвиняемого с согласия и в интересах подозреваемого, обвиняемого; а также адвокат об обстоятельствах, которые стали ему известны в связи с оказанием юридической помощи, за исключением случаев, если о допросе в качестве свидетеля ходатайствует адвокат с согласия лица, которому он оказывал юридическую помощь.

Нельзя не признать, что новая законодательная регламентация дачи адвокатами показаний в качестве свидетелей - значительный шаг вперед по сравнению с ранее действовавшей редакцией ч. 3 ст. 56 УПК РФ. Однако и в этом, новом, виде формулировки уголовно-процессуального закона вызывают определенные нарекания, поскольку дача адвокатом (защитником) показаний поставлена законодателем в зависимость исключительно от его усмотрения.

В процессе взаимодействия адвоката (защитника) с подзащитным между ними возникают правовые отношения, основанные на нормах УПК РФ. Необходимым элементом этих отношений выступает доверие. Так, общаясь с адвокатом (защитником), обвиняемый (подозреваемый) сообщает ему информацию об обстоятельствах дела, рассказывает о событиях, которые, возможно, не известны органам расследования или суду. Эти сведения необходимы адвокату для построения защиты и опровержения обвинительного тезиса. Без доверительных отношений защитник не мог бы получить от подзащитного всю необходимую информацию, что, в свою очередь, сделало бы невозможным осуществление им эффективной защиты от обвинения. Именно институт адвокатской тайны, гарантируемой положениями ч. 2 ст. 8 Федерального закона от 31 мая 2002 г. № 63-Ф3 «Об адвокатской деятельности и адвокатуре в Российской Федерации», а также п. 2, 3 ч. 3 ст. 56 УПК РФ, лежит в основе доверия подзащитного к адвокату (защитнику). 
На практике могут возникать ситуации, когда доверитель ходатайствует о допросе адвоката (защитника) в качестве свидетеля об обстоятельствах, ставших известными доверенному лицу в связи с обращением к нему за юридической помощью или в связи с ее оказанием. Однако закон позволяет адвокату уклониться от дачи свидетельских показаний, например, не заявив соответствующего ходатайства (п. 3 ч. 3 ст. 56 УПК РФ). Такое положение представляется неправильным. Необходимо иметь в виду, что «институт адвокатской тайны не следует рассматривать как личную привилегию, защищающую интересы адвоката и позволяющую ему без приведения мотивов отказываться от дачи свидетельских показаний, поскольку это противоречит основному назначению рассматриваемого института» [1, с. 53]. Посредством участия в деле защитника обвиняемый (подозреваемый) реализует свой процессуальный интерес. Защитник выполняет возложенную на него законом обязанность защитить интересы именно обвиняемого (подозреваемого). В связи с этим возможность дачи адвокатом свидетельских показаний должна быть, по нашему мнению, поставлена в зависимость от усмотрения доверителя, а не самого адвоката.

\section{Сохранение адвокатской тайны помощником и стажером адвоката}

Доступ к сведениям, составляющим адвокатскую тайну, имеют не только адвокаты, но и иные лица, в частности помощник, стажер адвоката, иные сотрудники адвокатских образований. Именно по этой причине Федеральным законом от 31 мая 2002 г. № 63-Ф3 «Об адвокатской деятельности и адвокатуре в Российской Федерации» на этих лиц возложена обязанность сохранять адвокатскую тайну (ч. 3 ст. 27, ч. 3 ст. 28). Кодекс этики адвокатов развивает эти положения, предусматривая, что помощники и стажеры адвоката, а также иные сотрудники адвокатских образований письменно предупреждаются о необходимости сохранения адвокатской тайны и дают подписку о ее неразглашении (ч. 10 ст. 6).
Однако в УПК РФ право помощника, стажера адвоката и иных сотрудников адвокатских образований отказаться от дачи показаний об обстоятельствах, ставших им известными в связи с их профессиональной деятельностью, не закреплено. Нельзя исключать на практике возможность возникновения ситуации, когда помощник, стажер адвоката или иной сотрудник адвокатского образования будет вызван следственными органами или судом для допроса в качестве свидетеля. При отказе дать свидетельские показания об обстоятельствах, ставших им известными в ходе осуществления профессиональной деятельности, то есть фактически составляющих предмет адвокатской тайны, они могут быть привлечены к уголовной ответственности по ст. 308 УК РФ.

\section{Выводы}

Во-первых, возможность адвоката уклониться от дачи свидетельских показаний об обстоятельствах, ставших ему известными в связи с обращением к нему за юридической помощью или в связи с ее оказанием, когда в этом заинтересован доверитель, нарушает права последнего. Во-вторых, отсутствие в законе права помощника, стажера адвоката отказаться от дачи показаний об обстоятельствах, ставших им известными в связи с их профессиональной деятельностью, фактически лишает институт адвокатской тайны необходимых правовых гарантий, что подрывает право обвиняемого (подозреваемого) на защиту. Для преодоления сложившейся ситуации считаем целесообразным внести изменения в п. 2 и 3 ч. 3 ст. 56 УПК РФ, изложив их в следующей редакции:

«2) защитник подозреваемого, обвиняемого - об обстоятельствах, ставших ему известными в связи с обращением к нему за юридической помощью или в связи с ее оказанием, за исключением случаев, когда о его допросе в качестве свидетеля ходатайствует лицо, которому оказывалась юридическая помощь;

3) адвокат, помощник адвоката, стажер адвоката - об обстоятельствах, которые стали ему известны в связи с оказанием юридической помощи, за исключением случаев, ког- 
да о его допросе в качестве свидетеля ходатайствует лицо, которому оказывалась юридическая помощь».

\section{СПИСОК ЛИТЕРАТУРЫ}

1. Дикарев, И. Свидетельские показания адвоката по ходатайству его доверителя / И. Дикарев // Законность. - 2006. - № 8. - С. 50-53.

2. Дикарев, И. С. Устранение от свидетельства в уголовном процессе / И. С. Дикарев // Уголовное право. -2011 . - № 5. - С. 61-65.

3. Колоколов, Н. А. Вызов адвоката на допрос в качестве свидетеля: критерии законности / Н. А. Колоколов // Адвокатская практика. - 2016. - № 5. C. 3-7.

4. Практика применения Уголовно-процессуального кодекса Российской Федерации. В 2 т. Т. 1 / под ред. В. М. Лебедева. - М. : Юрайт, 2016. - 231 с.

5. Таран, А. С. Допрос адвоката о производстве предварительного расследования в дисциплинарной практике адвокатских палат Российской Федерации / А. С. Таран // Адвокат. - 2016. - № 7. С. 5-8.

6. Таран, А. С. Свидетельский иммунитет адвоката: исторические параллели / А. С. Таран // Адвокатская практика. - 2016. - № 1. - С. 56-61.

\section{REFERENCES}

1. Dikarev I.S. Svidetelskie pokazaniya advokata po khodataystvu ego doveritelya [Witness Testimony of an Attorney at the Request of His Principal]. Zakonnost, 2006, no. 8, pp. 50-53.

2. Dikarev I.S. Ustranenie ot svidetelstva $\mathrm{v}$ ugolovnom processe [Elimination of Evidence in Criminal Proceedings]. Ugolovnoe pravo, 2011, no. 5, pp. 61-65.

3. Kolokolov N.A. Vyzov advokata na dopros v kachestve svidetelya: kriterii zakonnosti [Invitation of Lawyer to Questioning as a Witness: Legality Criteria]. Advokatskaya praktika, 2016, no. 5, pp. 3-7.

4. Lebedev V.M., ed. Praktika primeneniya Ugolovno-protsessualnogo kodeksa Rossiyskoy Federatsii. V 2 t. T. 1 [The Practice of Application of the Criminal Procedure Code of the Russian Federation. In 2 vols. Vol. 1]. Moscow, Yurayt Publ., 2016. 231 p.

5. Taran A.S. Dopros advokata o proizvodstve predvaritelnogo rassledovaniya $\mathrm{v}$ distsiplinarnoy praktike advokatskikh palat Rossiyskoy Federatsii [Interrogation of the Lawyer about Preliminary Investigation in the Disciplinary Practice of Bar Chambers in the Russian Federation]. Advokat, 2016, no. 5, pp. 5-8.

6. Taran A.S. Svidetelskiy immunitet advokata: istoricheskie paralleli [Witness Immunity of the Lawyer: Historical Parallels]. Advokatskaya praktika, 2016, no. 1, pp. 56-61.

\section{Information about the Author}

Irina A. Biryukova, Postgraduate Student, Department of Criminal Procedure and Criminalistics, Volgograd State University, Prosp. Universitetsky, 100, 400062 Volgograd, Russian Federation, ir_bir@bk.ru, upik@volsu.ru.

\section{Информация об авторе}

Ирина Анатольевна Бирюкова, аспирант кафедры уголовного процесса и криминалистики, Волгоградский государственный университет, просп. Университетский, 100, 400062 г. Волгоград, Российская Федерация, ir_bir@bk.ru, upik@volsu.ru. 